\title{
Oral Mucosal Cytological Changes among Miraa Chewers in Meru Kenya
}

\author{
Nelly Akinyi Ogada, Dr. Muchiri L.W. Dr. Ndung’u J.R. \\ A Dissertation Submitted in Part Fulfilment of the Award of Masters of Science Degree in Clinical cytology at \\ the University of Nairobi \\ MBChB, MMed (Path), PG-BRM, PhD Senior Lecturer Department of Human Pathology-UON \\ MBChB, MMed (Path) Lecturer Department of Human Pathology-UON
}

\begin{abstract}
:
Background: Miraa, qat, chat, cat, ghat or khat (Catha edulis), is a shrub indigenous to Eastern Africa and Arabic countries. It is cultivated in most Africa countries. Chewed miraa has sympathomimetic and euphoric effects and its chewing is a popular habit among some populations in Kenya. Habitual miraa chewing has been associated with oral lesions including oral cancer. It has also been associated with various toxic effects on the central nervous system, cardiovascular and reproductive system. In Kenya no data exists among the population that chew miraa of oral mucosal changes associated with miraa chewing.

Study Objective: To describe cytological changes of the oral mucosa among habitual miraa chewers in Meru Kenya.

Setting: Recruitment was done in miraa selling and chewing kiosks in Meru town. Sample collection and specimen processing was done at Meru level $V$ hospital and KNH/UON cytology laboratory respectively.

Subjects: Two hundred and nineteen (219) consenting participants aged 18 years and above with a history of chewing miraa for more than three years were recruited.

Design and method: This is a cross-sectional study. A total of 219 consenting adults who met the inclusion criteria were recruited. Snowball sampling technique was also used to hasten enrolment. Buccal smears were collected using cytobrush and examined to determine oral mucosal cytological changes while face to face interviews was used to collect social demographic data as well as risk factors for oral mucosal disease.

Data management and statistical analysis: Frequency and percentages were used to describe the patterns of oral mucosal cytology including the occurrence of neoplastic lesions. All statistical analyses were performed using STATA version 12.

Results: Most of the participants were male with an average age of 28.73 years. Majority, $99.5 \%$ were negative for oral mисоsal neoplasia and $0.5 \%$ had atypical squamous cells of undetermined significance. A few of the participants (2.3\%) had bacterial infection and non-specific inflammation - probably more due to poor oral hygiene than miraa chewing.

Age, quantity of miraa chewed and the length of time the bolus stay in the mouth were not associated with oral lesions. The average duration that this study group had chewed miraa was 5 years and this does not seem to have been significantly associated with oral lesions. The other risk factors including cigarette smoking, use of illicit drugs and alcohol use were not associated with oral lesions.

Conclusion: Inflammatory lesions were the most common cytologic finding in miraa chewers in this population. Oral mucosal neoplasia is not common in short term (5years) miraa chewers in Meru. Analysis of association of risks factors with neoplastic lesions in miraa chewers was performed and found not to be significant.

Recommendation:

1. A longitudinal study which will include older age group who probably have had a longer exposure to miraa should be carried out.

2. Promotion of oral hygiene to reduce oral inflammatory disease.
\end{abstract}

\section{Introduction}

Oral and pharyngeal cancers combined represent the fifth most common type of cancer and the seventh most common cause of deaths by cancer worldwide, although oral cancer is more common than pharyngeal cancer (1). Oral and pharyngeal cancers are three times more common in males than in females (2). Factors such as alcohol, tobacco, diet low in fruits and vegetables, Human Papillomavirus (HPV) infection and excessive sun exposure have been associated with oral cancer as well as habitual miraa chewing (3-6).

The harmful effects of miraa chewing have been observed in various body systems (7). Most of the active compounds of miraa are released into saliva during chewing and are mainly absorbed through the oral mucosa (8). The oral mucosa is thus exposed to high doses of miraa components, rendering it susceptible to 
potentially toxic effects. Miraa chewing induces oral keratotic white lesions on the buccal mucosa of miraa chewers. These lesions have been shown to occur specifically at the regions where the miraa bolus is placed during chewing (9). Miraa is genotoxic to cells in the oral mucosa, with several studies suggesting an association between miraa use and oral lesions like hyperkeratosis and oral cancer.

Current reports show that the prevalence of oral cancer associated with miraa chewing is on the increase both in the developed and developing countries (4). The carcinogens acquired from miraa chewing lead to acquisition of genomic disorders promoting malignancy. Two types of precancerous lesions in the oral cavity are identified, the principal precancerous lesion being white lesions (leukoplakia) and the less common red lesions (erythroplakia) (10). A high prevalence of oral leukoplakia in any population is a strong indicator of risk for oral cancer. In addition, the use of tobacco has generally been accepted as the principal etiologic factor for oral Leukoplakia $(11,12)$. However, the observation of this lesion in individual who do not use tobacco implies that non-tobacco factors may also play a role $(13,14)$. Alcohol and miraa have been suspected as possible etiological co-factors for oral mucosal cancer, but their independent roles have not been established $(14,15)$.

In Kenya, in addition to using tobacco, the Ameru people widely use alcohol and miraa, which are popular because of their socio-cultural values in this community. This ethnic group is ranked high among communities most affected by both oral and naso-pharyngeal carcinomas because of the high cultivation and consumption of miraa (14).

The success of oral cancer prevention in this region will rely on the better understanding of the prevalence, risk factors and identification of possible etiological factors involved, identification of precancerous lesions through screening as well as management of these pre-cancerous lesions. This study therefore sought to describe the oral mucosal cytological changes associated with miraa chewing among the Ameru people, and document other factors associated with oral mucosal lesions.

\subsection{Background}

\section{Literature Review}

Miraa (Catha edulis) also known as qat, chat, cat, ghat or khat first described in 1237 is a cultivated green bush plant with natural range extending throughout East Africa from Ethiopia, Eritrea and Somalia, through to South Africa; it is also found in Rwanda, Zaire, Malawi and Zimbabwe $(9,14,16)$. Catha edulis is also found sporadically in Afghanistan, Israel, Saudi Arabia, Syria and Turkistan (17). In Kenya, miraa is grown intensively in the Nyambene Hills district by the Tigania and Igembe (sub-groups of the Meru). It is of prime economic importance for the region where it feeds a growing international, as well as national market (18). Its use as a stimulant is gradually spreading to other parts of the World especially in immigrant communities $(8,13)$.

The fresh succulent stems and leaves are harvested regularly from the trees, and are highly valued for their stimulating properties. Cathinone, the major constituent of miraa is a natural amphetamine which has psychoactive effects; produces an initial euphoria that is later followed by depression, chewers may also experience irritability and insomnia (19). Harmful effects of miraa have been reported in various body systems (7). Most of the active compounds of miraa are released into saliva during chewing and are mainly absorbed through the oral mucosa (8). The oral mucosa is thus exposed to high doses of miraa constituents, rendering it susceptible to potentially toxic effects. Miraa chewing is associated with oral cavity histologically demonstrable changes like hyperkeratosis, epithelial hyperplasia, and mild dysplasia and increased periodontal disease including oral cancer $(8,15,16)$.

\subsection{Cultivation}

Catha edulis (miraa in Kenya), is a dicotyledonous evergreen shrub of the family Celastraceae (20). Scientifically first classified as C. edulis in Flora-Aegyptiaco-Arabia by the Swedish botanist Peter Forskal in 1768. The genus Catha also encompasses another member, $C$. spinosa, found only in Yemen where it exists in the wild state and at lower elevations (21). Under natural conditions, miraa grows in and on the margins of dry evergreen forest and mist forest. It grows naturally at elevations of 1500-2000 meters but is found at altitudes of 1200-2500 meters (22). It is best cultivated at high elevations, with high rainfall in acidic, well-drained clay soils; but can survive long periods of drought. The miraa tree has a slender bole and white bark with the tree ranging from 1 to 25 meters depending on the country of origin; however, annual pruning keeps their height to about 5 meters (18). Miraa cultivars vary considerably in their general appearance depending on the ecological conditions (23). The leaves are elliptic to oblong, pendulous, leathery, bright green and shiny above, paler below with evenly serrated edges. They are $5-10 \mathrm{~cm}$ long and $1-4 \mathrm{~cm}$ wide. Miraa tree is rarely affected by diseases and can live up to $75-100$ years if taken care of properly (17).

\subsection{Economic importance of Miraa}

About 10 million people globally chew miraa on a daily basis (24). In places where it is grown on a large scale such as in the horn of Africa and the Arabian countries, miraa chewing has a long history as social 
custom involving men and to a lesser extend females. In Yemen, between 1970 and 2000 the area devoted to miraa cultivation ballooned from 8000 to 103000 hectares (25). Miraa farming and marketing has become a large branch of Yemeni economy and a source of income for many who would otherwise be jobless. In Kenya while the economy has languished in the doldrums, miraa cultivation and marketing has boomed, impervious to national trends and international disapproval. All those involved in the industry agree that more miraa is grown, picked, and traded in Kenya today than ever before. Domestic consumption now extends beyond traditional miraa-chewing communities, with even ethnic groups with no history of use reported to be taking it up. A bundle of miraa retails from Ksh 500 to 3000 depending on the variety, seasons and location of origin (18). Outside Kenya, Tanzania has become a big new market, and the Somali miraa market demands have increased. The demand in Somalia is so high that in 2006, 20 tons (worth US\$ 800,000) were shipped daily from Kenya (17). The trade of miraa in one Somali city alone (Hargeisa) is estimated at US\$ 300,000 a day. In the USA miraa is being sold for US\$ 300-500 a kilo, with a bundle of leaves selling for US\$ 30-50. Strangely, no accurate figures are available to quantify the trend. The Kenyan government does not classify miraa as a cash crop, so the authorities ignore it, neither tracking its sale nor offering support to its growers . Conservative estimates shows that Kenya produces an estimated 150 tons of miraa a week which earns about Ksh19 billion with an estimated 500,000 sustained jobs per year (26). In a 5-year period study showed that Kenya exported horticultural products valued at Ksh30.5 billion, six times the value of imports (Ksh4.8 billion). Overall, Miraa was Kenya's biggest export product in terms of value, followed by processed fruits and vegetables (26).

\subsection{Composition of miraa}

The environment and climate dictates the chemical profile of miraa leaves. The taste of miraa leaves varies from one type to another and depends on the tannic acid content. The leaves have an astringent taste and a characteristic aromatic odour. The young leaves are slightly sweet (17). Various compounds (over 40) have been identified in miraa, including alkaloids, terpenoids, flavonoids, sterols, glycosides, tannins, amino acids, minerals and others (27) The phenylalkylamines and cathedulins are the major alkaloids. The miraa phenylalkylamines comprise cathinone (S-(-)-cathinone) and the two diastereoisomerscathine (1S, 2 S-(+)norpseudoephedrine or (+)-norpseudoephedrine) and norephedrine (1R,2 S-(-)- norephedrine). These compounds are structurally related to amphetamine and noradrenaline $(17,28)$. Cathinone is found mainly in the young leaves and shoots. During maturation, cathinone is metabolized to cathine, norpseudoephedrine and norephedrine. Other phenylalkylamine alkaloids identified in miraa leaves includes; the phenylpentenylamines merucathinone, pseudomerucathine and merucathine which contribute less to the stimulant effect of miraa $(17,27,28)$. Cathinone is unstable and undergoes decomposition reactions after harvesting and during drying or plant constituent extraction. Decomposition leads to a dimer (3,6-dimethyl-2,5-diphenylpyrazine) and possibly to smaller fragments. As cathinone is presumably the main psychoactive component of miraa, this explains why fresh leaves are preferred by the users. The phenylalkylamine content of miraa leaves varies within quite wide limits. On average, $100 \mathrm{~g}$ fresh miraa leaves contain 36-114 mg cathinone, 83-120 mg cathine and 8-47 mg norephedrine (8). Miraa leaves also contain considerable amounts of tannins and flavonoids $(29,30)$.

\subsection{Toxicology and adverse reactions of miraa in humans}

The adverse effects of miraa are summarized in Table 1.

Table 1: Toxicity and side effects of miraa in humans [modified from Balint et al (17)]

\begin{tabular}{|c|c|c|}
\hline Cardiovascular system & Gastrointestinal system & Hepatobiliary system: \\
\hline $\begin{array}{l}\text { tachycardia } \\
\text { palpitations } \\
\text { hypertension } \\
\text { arrhythmias } \\
\text { vasoconstriction } \\
\text { myocardial infarction } \\
\text { cerebral hemorrhage } \\
\text { pulmonary edema) }\end{array}$ & $\begin{array}{l}\text { dry mouth } \\
\text { polydypsia } \\
\text { dental caries } \\
\text { periodontal disease } \\
\text { chronic gastritis } \\
\text { constipation } \\
\text { hemorrhoids } \\
\text { paralytic ileus } \\
\text { weight loss } \\
\text { duodenal ulcer } \\
\text { upper gastrointestinal malignancy }\end{array}$ & $\begin{array}{l}\text { fibrosis } \\
\text { cirrhosis }\end{array}$ \\
\hline Genitourinary system & Respiratory system & Obstetric effects \\
\hline $\begin{array}{l}\text { urinary retention } \\
\text { spermatorrhea } \\
\text { spermato } \\
\text { zoa- } \\
\text { malforma } \\
\text { tions } \\
\text { impotence } \\
\text { libido change } \\
\end{array}$ & $\begin{array}{l}\text { tachypnoea } \\
\text { bronchitis }\end{array}$ & $\begin{array}{l}\text { low birth weight } \\
\text { stillbirths } \\
\text { impaired lactation }\end{array}$ \\
\hline Metabolic and endocrine effects & Ocular effects & Central nervous system \\
\hline hyperthermia & blurred vision & dizziness \\
\hline
\end{tabular}




\begin{tabular}{|c|c|c|}
\hline $\begin{array}{l}\text { perspiration } \\
\text { hyperglycemia }\end{array}$ & mydriasis & $\begin{array}{l}\text { impairedcognitive } \\
\text { function } \\
\text { fine tremor } \\
\text { insomnia } \\
\text { headache }\end{array}$ \\
\hline \multicolumn{3}{|l|}{ Psychiatric effects } \\
\hline $\begin{array}{l}\text { lethargy } \\
\text { irritability } \\
\text { anorexia } \\
\text { psychotic reactions } \\
\text { depressive reactions } \\
\text { hypnagogic hallucinations }\end{array}$ & & \\
\hline
\end{tabular}

Generally chewing miraa has been shown to affect almost all human systems, organs and functions. The main toxic effects include increased blood pressure, tachycardia, insomnia, anorexia, constipation, general malaise, irritability, migraine and impaired sexual potency in men (31). Further, miraa affects the nervous system and can induce paranoid psychosis and hypomaniac illness with grandiose delusions. Miraa induces cardiovascular complications by increasing episodes of acute myocardial infarction during or after miraa chewing episodes $(32,33)$. Miraa chewing has also been reported to be a significant risk factor for acute cerebral infarction (34). This same study by Mujlli HM et al also showed significantly higher blood pressure among miraa chewers than non-chewers. Miraa chewing also induces gastrointestinal complications: miraa chewing affects the oral cavity and certain parts of the digestive tract (17). The tannins present in the leaves are thought to be responsible for the gastritis that has been observed in miraa chewers. Chewing miraa reduces the absorption of ampicillin and to a lesser extent that of amoxicillin but the effects are minimal, lasting two hours after miraa chewing stops (35). Detailed studies on the possible effects of miraa chewing on human reproduction system are lacking. However, the few available data suggest that chronic use may cause spermatorrhea and may lead to decreased sexual function and impotence(36).

\subsection{Oral cancer}

Oral (the lips, teeth, and gums, the front two-thirds of the tongue, buccal mucosa, under the tongue, hard palate and the small area behind the wisdom teeth) and pharyngeal (the back one-third of the tongue, the soft palate, the tonsils and the back of the throat) cancers combined represent the fifth most common type of cancer and the seventh cause of deaths by cancer worldwide, although oral cancer is more common than pharyngeal cancer (1). Oral and pharyngeal cancers are three times more common in males than in females (2). Alcohol and tobacco are known risk factors for oral, pharyngeal, hypopharyngeal and nasopharyngeal cancers $(3,4,37)$. There is evidence of a dose-response relationship between their consumption and the occurrence of these cancers, as well as a strong interaction between them. It has also been reported that a diet low in fruits and vegetables, Human Papillomavirus (HPV) infection and excessive sun exposure are associated with a risk of oral and pharyngeal, hypopharyngeal and nasopharyngeal cancers $(5,38)$.

\subsubsection{Types of oral cancer}

Table 2 shows the different types of oral neoplasms. Some oral tumors are benign (non-cancerous), some may be precancerous (a condition that may become cancerous), while others may be cancerous. Different types of oral cancer may develop in different areas of the mouth and throat. The precancerous conditions in the mouth are grouped into the leukoplakia and erythroplakia. The leukoplakia a condition characterized by a whitish patch that develops inside the mouth or throat while erythroplakia is characterized by a red, raised patch that develops inside the mouth. Only 25 percent of leukoplakias develop into cancer while 70 percent of erythroplakias are found to be cancerous (39). Often caused by smoking or chewing tobacco, these (initially) benign conditions can occur anywhere in the mouth. Only a biopsy can determine whether precancerous cells (dysplasia) or cancer cells are present in a leukoplakia or erythroplakia.

Squamous cell carcinoma is the most common type of oral cancer. About $40 \%$ of squamous cell carcinomas begin on the floor of the mouth or on the side or bottom of the tongue, and another $40 \%$ occur on the lower lip. The remainder begins on the roof of the mouth or the tonsils. These cancers form a hard lump or a firm-bordered sore (ulcer) that may bleed intermittently (39). Affected areas may appear white, red, or mixed white and red and can be smooth or raised. Another variant of squamous cell carcinoma is verrucous (warty) carcinoma, which appears as a white grooved surface on the lining of the mouth or mucosa (40). Other types of cancer, such as malignant melanoma and Kaposi's sarcoma are less common. Malignant melanoma is usually associated with a history of sunburns and occurs on the surface of the skin. However, it occasionally occurs in the mouth, most commonly on the roof of the mouth, usually as a result of spread from a skin site. A malignant melanoma often has uneven, irregularly shaped borders and ranges in color from dark blue or brown to black. Its colour may be spotty, or even speckled. As with most cancers, it occasionally bleeds. Kaposi's sarcoma is a 
cancer of the blood vessels near the skin and in the lining of the mouth and throat. In people with AIDS, when Kaposi's sarcoma occurs in the mouth, it usually occurs on the roof of the mouth. The tumor is usually blue or purple and is slightly raised $(40,41)$.

Cancers of the salivary glands are much less common than noncancerous growths. The most common salivary gland cancer is mucoepidermoid carcinoma, which typically forms in a small minor salivary gland on the roof of the mouth. It may also occur as a lump in one of the large (major) salivary glands, either under or behind the lower jaw. Cancers of the jawbone include osteosarcoma and metastatic tumors (those that have spread to the jaw from another part of the body) $(40,41)$.

Table 2: Types of oral tumours (39-41)

\begin{tabular}{|c|c|}
\hline BENIGN TYPE & DESCRIPTION \\
\hline $\begin{array}{l}\text { Condyloma acuminatum (also known as } \\
\text { viral warts) }\end{array}$ & A small, moist, pink or red growth that grows alone or in cauliflower-like clusters \\
\hline Eosinophilic granuloma & $\begin{array}{l}\text { A benign tumor that most often affects children and adolescents and is usually found } \\
\text { in a bone or the lungs }\end{array}$ \\
\hline Fibroma & A benign tumor consisting of fibrous connective tissues \\
\hline Odontogenic tumors & tumors in the jaw that start in the tooth-forming tissues \\
\hline Leiomyoma & $\begin{array}{l}\text { A tumor of the smooth muscle, often found in the esophagus, small intestine, uterus, } \\
\text { or stomach }\end{array}$ \\
\hline Rhabdomyoma & $\begin{array}{l}\text { A striated-muscle tumor that may appear on the tongue, pharynx, uterus, vagina, or } \\
\text { heart }\end{array}$ \\
\hline Papilloma & $\begin{array}{l}\text { A tumor that resembles a wart, growing on the epithelium (the cells that form the } \\
\text { skin and mucous membranes) }\end{array}$ \\
\hline Verruciform xanthoma & Wart-shaped tumors \\
\hline MALIGNANT TYPE & DESCRIPTION \\
\hline Minor salivary gland cancers & $\begin{array}{l}\text { The lining of the oral cavity and oropharynx contains numerous salivary glands. } \\
\text { Rarely cancer may originate in a salivary gland. Treatment depends on the type and } \\
\text { location of the salivary gland cancer, as well as the extent of spread. }\end{array}$ \\
\hline
\end{tabular}

\subsection{Miraa and oral cancer}

It has been speculated that there might be an association between miraa chewing and oral malignancies (42). It has been reported that about $50 \%$ of miraa chewers develop oral mucosal keratosis (43). This pathologic change is considered a pre-cancerous lesion that may develop into oral cancer (44). Keratotic white lesions are present in the mouths of about one-fifth of miraa-chewers (9). This change in pathology is recognised as precancerous and may develop into oral cancer (44). Buccal epithelial cells experience genotoxic effects in a doserelated way in miraa-chewers; this suggests that oral malignancies can be contributed to by miraa (45). The prevalence of this lesion and its severity increased with frequency and duration of miraa use (45). The importance of miraa and oral malignancies have been documented after finding that most of the oral squamous cell carcinomas are located in the buccal mucosa and lateral sides of the tongue, which come into direct contact with miraa during chewing (45).

\subsection{Epidemiology of miraa induced oral cancer}

Macigo et al (1995) reported that although they found oral leukoplakia in few of the miraa users examined in Kenya, no significant association between chewing miraa and leukoplakia was seen. Hill and Gibson, (1987) reported that oral white lesions, resembling those of frictional keratosis, were noted in $50 \%$ of miraa chewers in Yemen. In the mouth, frequent and prolonged time period of miraa chewing may cause stomatitis, pain at the site of chewing, stress and staining on teeth (9). Hill and Gibson reported in their study on 127 Yemeni in 1987 that some degree of oral keratosis, but not dysplasia or malignancy, was observed among qat chewers (43). However, they did not conduct any histopathological study to confirm the absence or presence of dysplasia or malignancy. A recent study concluded that miraa chewing increases the risk for several oral lesions including gingivitis, periodontitis, temporomandibular junction (TMJ) click and mouth dryness (45). In a survey in Saudi Arabia about 50\% of the patients with head and neck cancer presented with a history of miraa chewing and all of them had used miraa over a period of 25 years or more (42). In some cases (similar to Makki's observation) the malignant lesion occurred at exactly the same site as where the miraa bolus was held (42). The authors concluded that a strong correlation existed between miraa chewing and oral cancer. There is an increased risk of oral carcinoma amongst miraa chewers (42), especially when associated with alcohol and tobacco consumption (45). Miraa has been found to be a significant contributory factor in the high prevalence of 
head and neck squamous cell carcinoma in the Yemeni population (46). There may be a synergistic effect created by the consumption of alcohol, miraa, and tobacco, leading to the development of changes in cells that can become cancerous (45).

\subsection{Detection of oral pre-cancerous and cancerous lesions}

Early detection of oral cancer in asymptomatic stage dramatically improves patient's management and reduces morbidity and mortality (47). Unfortunately, the visual detection of oral cancer at an early stage is significantly hindered by the difficulty in clinically differentiating premalignant and malignant lesions from similar looking benign lesions. Scapel biopsy remains the accurate, reliable method for diagnosing oral mucosal abnormalities (48). However, the invasive nature of this method makes patient to be reluctant, and at times fearful, of such an invasive surgical procedure. The patients' reluctance may be compounded by the clinicians' hesitation to perform a surgical procedure in an unfamiliar setting or anatomical site (49). The use of cytobrush has a wide clinical application in assessment of surface oral and oropharyngeal mucosal abnormalities, which include leukoplakia and mixed red and white lesions, such as erythroplakia and speckled leukoplakia. Early assessment of such lesions leading to prompt identification of dysplastic preinvasive or early minimally invasive disease is central to eliminating these lesions. This permits high cure rates even in cases where invasive disease is noted on subsequent scapel (surgical or excision) biopsy.

\subsection{Justification}

As evidenced from the literature (review), oral cancer is a health problem which concerned

nations cannot afford to ignore. Miraa has been identified as one of the risk factors for development of oral cancer. The natural history of oral cancer gives opportunity to diagnose it at an early stage which if properly managed could lead to prevention of development to invasive stage.

Fortunately, there are methods for early detection including oral brush cytology which is cheap, noninvasive, fast and reliable hence potentially helpful because of high chance of acceptability by both the clients and medical practitioners. Methods for treating these non-invasive lesions are also available. This method would obviate surgery with its attendant risks while achieving a similar goal.

Kenya is one the largest producers and consumers of miraa, a herb associated with development of oral cancer. Currently, there is limited data in Kenya on the relationship of miraa chewing and oral disease and cancer in particular, justifying conduction of more studies to provide data and other risk factors for neoplastic and nonneoplastic oral disease.

\subsection{Research Question}

Are there cytological changes in oral mucosal cells of habitual miraa chewers in Meru, Kenya?

\subsection{Objectives}

\subsubsection{General objective}

To describe the cytological changes in oral mucosal cells of habitual miraa chewers in Meru, Kenya.

\subsubsection{Specific objectives:}

a) Primary

1. To describe the pattern of oral mucosal cytological findings among habitual miraa chewers.

2. To determine the prevalence of neoplastic lesions on oral mucosal cytology in habitual miraa chewers.

b) Secondary

3. To identify other potential risk factors, such as alcohol and tobacco use, associated with oral lesions among the habitual miraa chewers.

\subsection{Study site}

\section{Materials and Methods}

This study was conducted within Meru town in Kiosks and vendors of miraa, Dental Unit at Meru Level V hospital and KNH/UON cytology laboratory.

\subsection{Study design}

This was a cross-sectional descriptive study aimed at determining the prevalence and describing the pattern of oral mucosal cytological changes associated with habitual miraa chewing.

\subsection{Study population}

Consent and recruitment was done among adults aged 18 years and above, with a history of chewing miraa for at least 3 years. 


\subsection{Selection criteria}

3.4.1 Inclusion criteria

1. Persons (male or female) with a history of miraa chewing for over 3 years.

2. Adults 18 years and above

\subsubsection{Exclusion criteria}

1. A current diagnosis of oral cancer or squamous intraepithelial lesion rendered prior to enrolment.

2. Non consenting.

\subsection{Sample size determination}

The sample size was calculated using Fisher's formula. Oral white lesions prevalence of $83 \%$ was used having been obtained from a study in Tel Aviv, Israel (50)

$$
Z_{1-\alpha / 2}{ }^{2} \mathrm{P}(1-P)
$$

\begin{tabular}{|c|c|}
\hline $\begin{array}{l}n-S \\
Z_{I-\alpha / 2} \text { - Two-sided significanc } d^{2} \\
P \text { - Estimated proportion of } 1 \\
d-\text { - Precision error }= \pm 5 \% \\
\text { Substituting into the formula } \\
n=219 \text { miraa chewers. }\end{array}$ & $\begin{array}{l}95 \%=1.96 \\
\text {-al lesions. }\end{array}$ \\
\hline
\end{tabular}

Thus 219 habitual miraa chewers were consented and recruited.

\subsection{Sampling method}

The first phase of the study was to identify all or major kiosks, vendors of miraa sellers within Meru town. Once these miraa selling kiosks were identified the owners were requested to give an approximate list or numbers of miraa buyers from their kiosks. Two methods of sampling were employed to increase recruitment into the study. First, the study used convenient-consecutive sampling technique, with the help of research assistants, to randomly recruit all accessible and consenting habitual miraa chewers. The second technique was "snowball sampling technique" (getting habitual miraa chewers to refer those they know, these individuals in turn refer those they know and so on) which greatly hastened participants' recruitment. Data was collected from the initial participants who were given coded coupons to distribute to individuals from their social network that were eligible for the study. Their network contacts were requested to come to the study site, where they were interviewed and recruited into the study. In turn they were given coupons to distribute to the members of their own network; this went on until the required sample size was attained.

\subsection{Data and specimen collection}

Data collection was done in the following manner: socio-demographic data was obtained from the consenting participants and filled into pretested questionnaires. Oral assessment and the findings were recorded on the laboratory form. Collection of oral samples was done at the Meru Level V hospital. Lastly data pertaining to cytological findings was obtained following screening and signing out of the smears at KNH/UON cytology laboratory.

\subsection{Laboratory investigations \\ 3.8.1 Oral sample collection}

Research assistant (a nurse in the dental unit) instructed the participants to rinse their mouths with water before the smears were collected. A cytobrush was used to collect cells from surface layers of a lesion by vigorous abrasion. The preferred chewing site (where the miraa bolus stays) was the target site for collection. The collected specimen were smeared onto two clean pre-labelled glass slides and fixed in $95 \%$ alcohol immediately for at least 15 minutes.

\subsubsection{Staining method}

The smears were stained using Papanicolaou, Haematoxylin and Eosin staining methods(10). All the standard operating procedures (SOPs) for these methods of staining were followed to ensure and increase the reliability and reproducibility of the results. [Appendix IV] 


\subsubsection{Cytological assessment and Reporting}

All the samples were screened by the PI and signed out by the supervisors. The abnormal smears and $10 \%$ of the negative smears were signed out by an independent pathologist. Smears with discordant results were signed out by a different pathologist who was the tie breaker. Presence or absence of cytological findings and the non-epithelial components were reported using The Bethesda Reporting System (TBS) 2001 [Appendix V].

\subsection{Biosafety measures}

Aseptic procedures were employed during collection of samples. Protective gear was worn during receiving, storage, processing and analysis of samples. Fixed smears were arranged in safe slide boxes and transported to KNH/UON cytology laboratories were the specimens were processed following the SOPs.

\subsection{Variables}

The independent variable in this study is presence of oral mucosal lesions.

The relationship between presence of oral neoplasm lesions and the following dependable (covariates) were modelled: age, residence, gender, occupation, education level, marital status, duration (years) of chewing miraa, miraa bundles chewed per day, length of time miraa bolus stays in the mouth, frequency of chewing miraa, tobacco and bhang use, alcohol use and duration of use, use of other hard drugs, presence of oral cavity lesions, medication types for oral cavity lesions and other cytological findings.

\subsection{Data Management}

All participants were assigned a unique personal identification number (PIN). All data entered into the study databases were delinked and only associated with a PIN in password protected files. Double entry system for the data was maintained. All paper research records were kept in a locked filing cabinet. The biological samples were being identified using PIN and were stored in boxes with restricted access.

\subsection{Statistical Analysis}

Statistical analysis was done using STATA version 12 (Stata Corp LP, Texas, USA) at a significance level of $\mathrm{P} \leq 0.05$. The prevalence of oral mucosal cytological changes and the distribution of the demographic characteristics were calculated using chi-square and presented in terms of frequency and percentage.

\subsection{Quality assurance}

Standard operating procedures of $\mathrm{KNH} / \mathrm{UON}$ were adhered to, those pertaining to labelling of slides, specimen collection, transportation, analysis and posting of results. Sample collection was done aseptically. Fixed and dried smears were packed in slide boxes and transported to KNH/UON cytology laboratory for processing and analysis. All reagents were prepared in accordance with standard operating procedures (SOPs) used at $\mathrm{KNH} / \mathrm{UON}$ cytology laboratory (Appendix IV). Equipment operation was done according to manufacturer's instructions. Screened smears were confirmed by the supervising pathologist before results were signed out to the participant's records. All positive smears and every fifth normal smear were re-screened by an independent pathologist. Where there was discrepancy a tie-breaker opinion was sought from a different pathologist.

\subsection{Ethical Considerations}

Permission to carry out the research was obtained from the UON/KNH ethics and research committee before commencement of the study.

The participants were carefully taken through a consent process that informed them about the study, benefits and risks involved and what was required of them.

Consenting eligible participants, with a nurse as a witness signed the consent form before they took part in the study. Any information obtained from the participants was kept strictly confidential and used solely for achieving the study objectives.

Participants were informed of their screening results in accordance with the established clinical practice and referred for further management to Meru level V Dental Unit when indicated.

\subsection{Demographic characteristics}

\section{Results}

A total of 219 habitual miraa chewers were consented and enrolled into the study, of these, 209 (95.5\%) were males, 214 (97.7\%) were residents of Meru town. Nearly half, 109 (49.8\%) had secondary level education and $120(54.8 \%)$ were single. 
There were three main occupation types business $68(31.1 \%)$, farming $54(24.7 \%)$ and various forms of employment $50(22.8 \%)$. A few were students $30(13.7 \%)$ and the least were those who were unemployed 17 (7.8\%) (Table 3)

Table 3: Demographic characteristics of study population $(\mathbf{n}=219)$

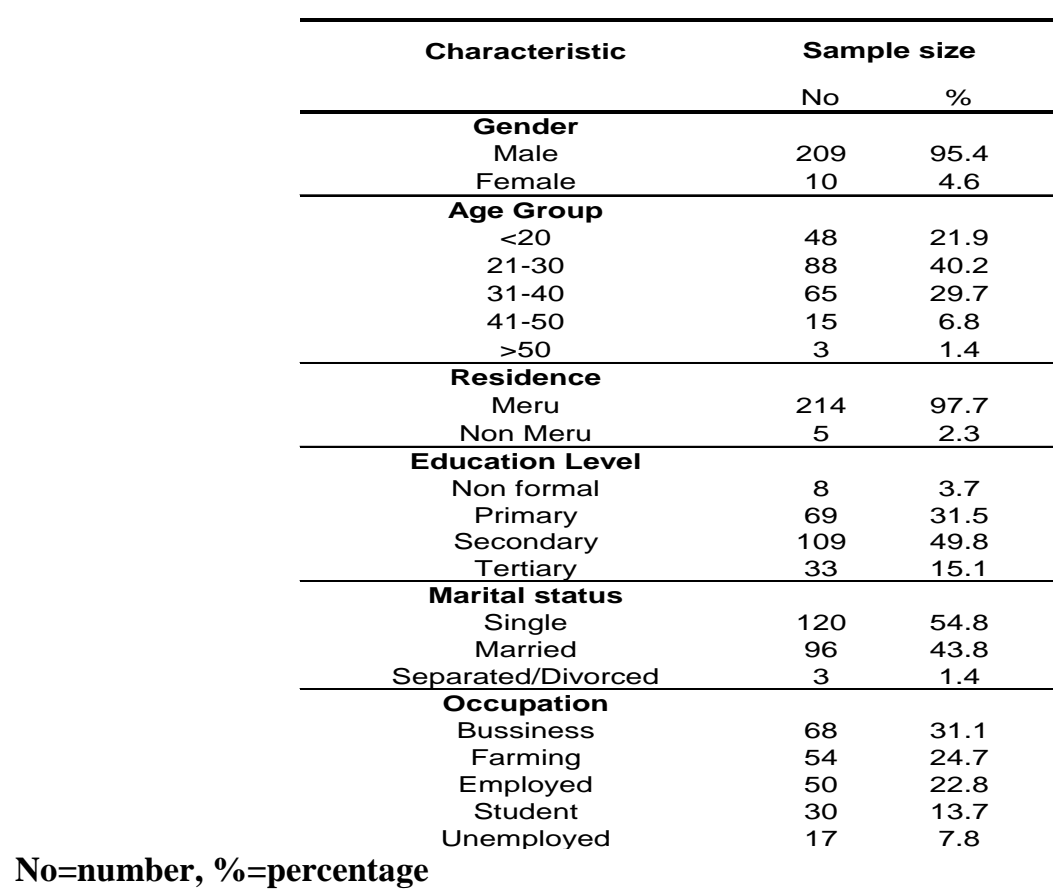

\subsection{Age distribution}

Mean age of the 219 participants was 28.73 years (range 17- 70 years) and there were three peak age groups; those aged 21 to 30 years $(40.2 \%)$, followed by those aged 31 to 40 years $(29.7 \%)$ and those age 20 years or younger $(21.9 \%)$ (Figure 1$)$.

Figure 1: The age distribution of study participants $(n=219)$

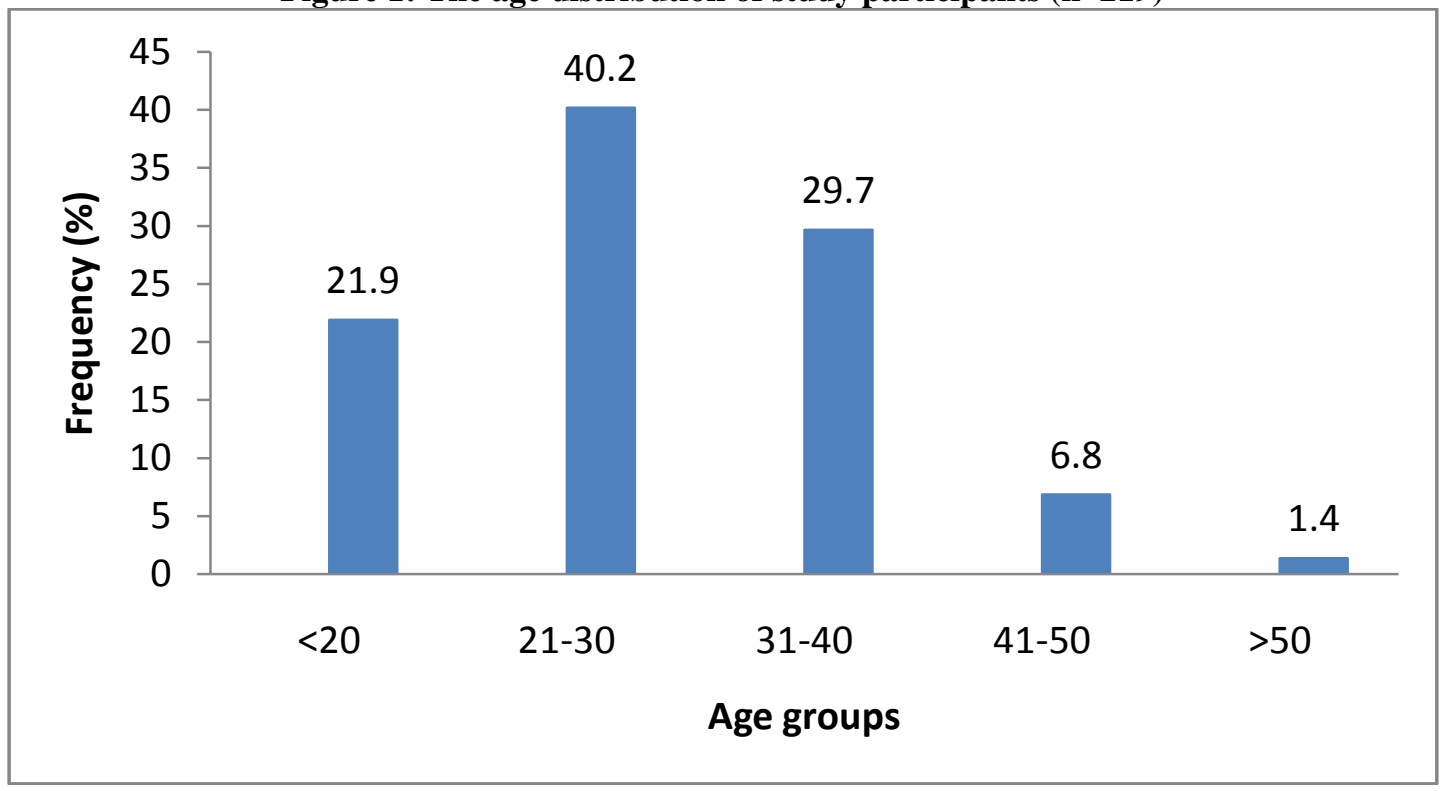

\subsection{Participants miraa chewing habits}

There were two distinct periods of times in which the participants chewed miraa (Table 4). Majority $84(38.4 \%)$ had chewed miraa for less than 5 years while $72(32.9 \%)$ had chewed miraa for more than 10 years. 
Table 4: Participants miraa chewing habits. $(n=219)$

\begin{tabular}{ccc}
\hline Characteristic & \multicolumn{2}{c}{ Sample size } \\
& No & $\%$ \\
\hline Years of Miraa chewing & \multicolumn{2}{c}{} \\
Less 5 & 84 & 38.4 \\
$5-10$ & 63 & 28.8 \\
$>10$ & 72 & 32.9 \\
\hline Frequency of miraa chewing & & \\
Daily & 197 & 90.0 \\
Twice a week & 2 & .9 \\
Thrice aweek & 4 & 1.8 \\
Once a week & 5 & 2.3 \\
Occassionally & 11 & 5.0 \\
\hline $1 \quad$ & \\
$1-3$ & 46 & 21.0 \\
$>3$ & 149 & 68.0 \\
\hline Daily miraa bundle chewed & 24 & 11.0 \\
\hline $1-6$ & 117 & 53.4 \\
$6-12$ & 100 & 45.7 \\
$>12$ & 2 & 0.9 \\
\hline Duration of miraa bolus in the mouth(hours) & \\
\hline
\end{tabular}

No $=$ Number, $\%=\overline{\text { Percentage }}$

In terms of the frequency of miraa chewing, majority 197 (90\%) chewed on a daily basis while a few $2(0.9 \%)$ chewed twice a week.

Concerning the bundle of miraa chewed daily majority $149(68 \%)$ chewed 1 to 3 bundles of miraa daily. The time miraa bolus was kept in the mouth during chewing was recorded; about half of the participants $117(53.4 \%)$ reported keeping their bolus for 1-6 hours and 100(45.7\%) reported keeping their bolus for 6-12 hours. Only 2(0.9\%) reported keeping miraa bolus in their mouth slightly over 12 hours.

4.4 Participants alcohol and smoking habits.

Table 5: Participants alcohol and smoking habits. $(\mathbf{n}=219)$

\begin{tabular}{|c|c|c|}
\hline \multirow[t]{2}{*}{ Characteristic } & \multicolumn{2}{|c|}{ Sample size } \\
\hline & No & $\%$ \\
\hline \multicolumn{3}{|l|}{ Smoking } \\
\hline Yes & 108 & 49.3 \\
\hline No & 111 & 50.7 \\
\hline \multicolumn{3}{|l|}{ Specific smoked } \\
\hline Cigarettes & 99 & 45.2 \\
\hline Cigarrets and Bhang & 6 & 2.7 \\
\hline Tobacco & 3 & 1.4 \\
\hline None & 111 & 50.7 \\
\hline \multicolumn{3}{|l|}{ Take Alcohol } \\
\hline Yes & 114 & 52.1 \\
\hline No & 105 & 47.9 \\
\hline \multicolumn{3}{|l|}{ Alcohol type } \\
\hline Bottled & 101 & 46.1 \\
\hline Bottled and Traditional & 5 & 2.3 \\
\hline Traditional & 8 & 3.7 \\
\hline None & 105 & 47.9 \\
\hline \multicolumn{3}{|l|}{ Quantity of alcohol } \\
\hline $1-5$ bottles & 103 & 47.0 \\
\hline 6-10bottles & 4 & 1.8 \\
\hline None & 112 & 51.1 \\
\hline \multicolumn{3}{|l|}{$\begin{array}{c}\text { Duration of alcohol } \\
\text { consumption }\end{array}$} \\
\hline Less 5 & 47 & 21.5 \\
\hline 5-10 & 62 & 28.3 \\
\hline$>10$ & 2 & .9 \\
\hline None & 108 & 49.3 \\
\hline \multicolumn{3}{|l|}{ Use of other hard drugs } \\
\hline Yes & 6 & 2.7 \\
\hline No & 213 & 97.3 \\
\hline
\end{tabular}

No $=$ Number, $\%=$ Percentage 
Table 5 above shows participants smoking and alcohol consumption practices. History of smoking from the participants was recorded with 100(49.3\%) reported smoking and 111(50.7\%) reported not smoking. Majority 99(45.2\%) smoked cigarettes while 6(2.7\%) smoked both cigarettes and bhang and 3(1.4\%) sniffed tobacco.

With alcohol consumption about half $114(52.1 \%)$ reported consuming and 105(47.9\%) reported not consuming. Bottled alcohol was the most consumed with $101(88.6 \%)$ followed by a few $8(7.0 \%)$ traditional brews and by $5(4.4 \%)$ of those who consumed both bottled and traditional alcoholic beverages.

Majority62 (28.3\%) of the participants, who consumed alcohol, consumed 5 to 10 bottles while $47(21.5 \%)$ had consumed alcohol for 1 to 5 years. Only about $6(2.7 \%)$ of the participants reported taking other had drugs.

\subsection{Clinical findings on oral cavity examination.}

Among the study participants $20(9.1 \%)$ had clinically observed lesions in the oral cavity, majority 16 $(80 \%)$ had blackened teeth and gums and $4(20 \%)$ had ulcerated lips (Table 6).

Table 6: Clinical characteristics of oral mucosal cavity $(\mathbf{n}=219)$

\begin{tabular}{ccc}
\hline Characteristic & \multicolumn{3}{c}{ Sample size } \\
& No & $\%$ \\
\hline Lesion in the cavity & 20 & 9.1 \\
Yes & 199 & 90.9 \\
No & & \\
Lesion type & 16 & 7.3 \\
Black teeth and gums & 4 & 1.8 \\
Ulcerated lips & &
\end{tabular}

No $=$ Number, $\%=$ Percentage

\subsection{Patterns of cytologic findings on oral mucosa}

Almost all the participants $211(96.3 \%)$ had negative (for intraepithelial lesion) oral mucosal cytological findings, three $(1.4 \%)$ were negative but had bacterial infection, two $(0.9 \%)$ were negative but with inflammation. Only one participant $(0.5 \%)$ had atypical cytology (Table 7$)$.

Table 7: Patterns of cytologic findings of oral mucosa in miraa chewers $(\mathbf{n}=219)$

\begin{tabular}{ccc}
\hline Characteristic & \multicolumn{2}{c}{ Sample size } \\
& No & $\%$ \\
\hline Cytopathology finding & & \\
Negative & 211 & 96.3 \\
Negative and Inflamation & 2 & .9 \\
Negative and Bacterial & 3 & 1.4 \\
Atypia & 1 & .5 \\
Unsatisfactory & 2 & .9 \\
\hline
\end{tabular}

No $=$ Number, $\%=$ Percentage

\section{Discussion}

The aim of this study was to describe oral cytological changes in miraa chewers among the residence of Meru town. A total of 219 habitual miraa chewers were consented and enrolled into the study. Majority of the participants in this study were male and this compares well with a similar study by Ahmed et al (16) where he found that miraa chewing is a predominantly male habit. However, the mean age was lower 28.7 years in this study compared to 47 years in the study by Ahmed et al (16).

Oral cytology using a cytobrush which was applied in this study was a simple and non-invasive technique that provided sufficient cells for analysis of non-neoplastic and neoplatsic oral lesions.

This study found one case with ASCUS. The rest $99.5 \%$ were negative for oral mucosal neoplasia. This is in contrast to Macigo et al (14) study conducted in rural Meru district in 15 year old and over, living in 
Githongo sub location who found the prevalence of oral neoplasia among miraa chewers to be $20 \%$. The population in Macigo's study had a mean age of 47 years while the mean age in this study was 28.7 years. This study recruited a younger population than Macigo et al (14) suggesting that Macigo et al (14) study participants might have had longer duration of chewing miraa hence more exposure and more time for the development of oral neoplastic lesions. The low prevalence of neoplastic lesions in this study does not suggest that miraa chewing is a safe habit but underscores the fact that carcinogesis is a process that is dependent on several factors including; time, type and amount of exposure to carcinogen, immune status of the individuals and other interventions. Time is an important factor in carcinogenesis, an example is given for cervical cancer where it takes about 10-20 years before precursor lesions develop into cancer. This therefore explains the reason for low prevalence in this generally younger population.

A few $(2.3 \%)$ had bacterial infection and inflammation; this may be attributed to poor oral hygiene which may have been as a result of chewing habits of keeping the bolus in the mouth for long periods and sometimes mixing it with other substances. Ali et al (9) in a study of oral keratotic lesions caused by qat chewing also found increased incidence of gingivitis among khat chewers but no neoplastic lesions. With increased prevalence of HIV/AIDS this could lead to increased chances of development of opportunistic infections in this population if they are HIV infected.

Several risk factors associated with oral lesions were evaluated in this study. They included alcohol use, smoked (cigaratte) and non-smoked tobacco and bhang. Despite the fact that a approximately half of the participants $(50.7 \%)$ consumed the above mentioned substances, there was no detectable association between use of these substances and development of oral neoplastic lesions. The only participant found to have a significant oral lesion did not consume either of the substances. Correlation of risk factors with oral neoplastic lesions could not be done due to the limited number of lesions observed in this study.

Chewing miraa in the short term does not seem to have deleterious effects but its long term use is more important in carcinogenesis and phenotypic cellular changes. From a preventive perspective, the observed prevalence of oral neoplastic lesions $(0.5 \%)$ undermines its public health significance in the study population; funds should be directed towards screening of the target group-with longer exposure.

\subsection{Conclusion}

1. Oral mucosal neoplasia is not common in persons with an average miraa chewing period of five or less years in Meru.

2. Inflammatory lesions were the most common positive findings and this could be attributed to poor oral hygiene.

\subsection{Recommendations}

1. A longitudinal study including an older age group who probably have a long time exposure or followup of young people who are likely to be long term miraa chewer should be carried out.

2. Promotion of oral hygiene is recommended so as to reduce oral inflammatory disease.

\subsection{Study Limitation}

The snowball sampling technique used in this study precluded age stratification. This led to predominance of young age group and this would have affected the outcome of this study. The participants recruitment sites, which were miraa selling and buying kiosk, were mainly visited by the young people hence the elderly who might have longer exposure period to miraa chewing were not accessed.

\section{Acknowledgement}

For the life within me and the many opportunities that are at my disposal, I am indebted to God. Thank you Father.

I am grateful to Technical University of Mombasa for the study leave and the sponsorship it awarded me, you just added to the medical-world a Cytologist; this rare field of study.

My supervisors, Dr. Muchiri and Dr. Ndung'u, you saw me from the project conceptualisation to results presentation and writing, 1 will forever be grateful to you. Thank you so much.

The Medical Superintendent and staff of Meru level V Hospital Dental clinic thank you so much for the assistance and support you gave me, it was a pleasure working with you.

The KNH/UON Cytology laboratory staff member's thank you so much for the support and encouragement you gave me.

My friends and colleagues, for the encouraging words and cheering me on, may God bless you.

And finally to my extended family members, you have been praying for me and understanding even when 1 stayed so long without calling or visiting with you. Thank you. 


\section{References}

[1] Punal-Rioboo J, Varela-Lema L, Barros-Dios JM . Occupation as a risk factor for oral and pharyngeal cancer. Acta Otorrinolaringo Esp. 2010; 61(5):375-83.

[2]. Food, nutrition, physical activity, and the prevention of cancer: a global perspective.World Cancer Research Fund/American Institute for cancer Research. 2007; 245-9

[3]. Bosetti C, Negri E, Francheschi S et al. Risk factor for oral and pharyngeal cancer in women: a study in Italy and Switzerland. British Journal of Cancer. 2000; 82:204-7.

[4]. Garrote LF, Herrero R, Reyes RM et al. Risk factor for cancer of the oral cavity and oro-pharynx in Cuba. British Journal of Cancer. 2001; 85:46-54.

[5]. Escribano UA, Rabanal RI, Garcia GA et al. Pharyngeal cancer prevention. Journal of Laryngolology Otology. 2002;116:523-31.

[6]. International Agency for Research on Cancer. IARC handbooks of cancer prevention. Lyon: IARC. 2003;

[7]. Al-Habori M. The potential adverse effects of habitual use of catha edulis (miraa). Expert opinion Drug safety. 2005;4:1145-54.

[8]. Toennes SW, Harder S, Schranm M et al. Pharmacokinetics of cathinone, cathine and norephedrine after the chewing of miraa leaves. British Journal of Clinical Pharmacology. 2003;56:125-30.

[9]. Ali AA. Histopathologic changes in oral mucosa of Yemenis addicted to water-pipe and cigarette smoking in addition to takhzeen al-qat. Oral surgery oral medicine oral pathology oral radiology and endodontics. 2007;(103):55-9.

[10]. Leopold G. Koss MRM. Koss' Diagnostic cytology and it's histologic bases. In: Leopold G. Koss MRM, editor. Lippincott Williams and Wilkins. 5th Edition. Linnincott Williams and Wilkins; 2006. p. 714-37.

[11]. WHO. Control of oral cancer in developing countries . Bulletin of the World Health Organzation. 1984; 62(6):817-30.

[12]. Axell T, Holmstrop P, Kramer IRH. International seminar on oral leukoplakia and associated lesions related to tobacco habits. Community Dental Oral Epidemiology $\square ; 1984 ; 12(145-154)$.

[13]. Baric JM, Alman JE, Feldman RS CH. Influence of cigarette, pipe and cigar smoking, removable partial dentures and age on oral leukoplakia. Oral Surgery. 1982; 54:424-9.

[14]. Macigo FG, Mwaniki DL, Githua SW. The association between oral leukoplakia and use of tobacco , alcohol and khat based on relative risks assessment in Kenya. European Journal of Oral Sciences. 1995; 268-73.

[15]. Gupta P. Epidemiological study of the association between alcohol habits and oral leukoplakia. Community Dental Oral Epidemiology. 1984; 12:47-50.

[16]. Ahmed HE, Omer ASA, Algaffar SAA. Cytological Study of Exfoliative Buccal Mucosal Cells of Qat Chewers in Yemen. Diagnostic Cytopathology. 2010; 39(11).

[17]. Balint GA, Baling EE. On the medico-social aspects of miraa (catha edulis) chewing habit. Human Psychopharmacology. 1994; 9(2):125-8.

[18]. Carrier N. " Miraa is Cool ": the cultural importance of miraa ( khat ) for Tigania and Igembe youth in Kenya. Journal of African Cultural Studies. 2005; 17(2):201-18.

[19]. Lukandu OM. Toxicity of Khat on Normal Human Oral Cells. 2009

[20]. Kennedy JG, Teague J, Rokaw W et al. A medical evaluation of the use of qat in North Yemen. Social science \& medicine 1983. p. 783-93. Available from: http://www.ncbi.nlm.nih.gov/pubmed/6879237

[21]. Al-Hebshi NN, Skaug N. Effect of khat chewing on 14 selected periodontal bacteria in sub- and supragingival plaque of a young male population. Oral Microbiology and Immunology; 2005; 20(3):141-6.

[22]. Corkery JM, Schifano F, Oyefeso A et al. Overview of literature and information on "miraa-related" mortality: a call for recognition of the issue and further research. Ann 1st Super Sanità. 2011; 47(4):445-64.

[23]. Simmons MP, Cappa JJ, Archer RH et al. Phylogeny of the Celastreae (Celastraceae) and the relationships of Catha edulis (qat) inferred from morphogical character and nuclear and plastid genes. Molecular phylogenet Enol. 2008;48(2):745-57.

[24]. Haight-Ashbury. Journal of psychoactive drugs. 2009; 41:3

[25]. Al-hebshi NN, Skaug N. Miraa (Catha edulis) — an updated review. Addiction Biology. 2005; 10:299-307.

[26]. Horticultural News 2012. Kenya's Intra Africa Horticultural Trade Executive Summary. http://www.hortinews.co.ke/article.

[27]. Nencini P, Ahmed AM. Khat consumption; a pharmacological review. Drug Alcohol Dependence. 1989; 23:19-29.

[28]. Dhaifalah I. Miraa habit and its health effect: a natural amphetamine. Biomed. Papers. 2004; 148(1):11-5.

[29]. Hassan NAGM, Grunaid AA, El-khally FMY et al. The subjective effects of chewing Qat leaves in human voluteers. Annal of Saudi Medicine. 2002; 22:34-7.

[30]. Al-Motarreb A, Baker K, Broadely KJ. Miraa-pharmacological and medical aspects and its social use in Yemen. Phytotherapy research. 2002;16(5):403-13

[31]. Cox G, Rampes H. Adverse effects of miraa. Adv Psychiatr Treat. 2003;9:456-63.

[32]. Al-Motarreb A et al. Miraa chewing and acute myocardial infarction. Heart. 2002; 87:279-80.

[33]. Al-Kadi HO, Norman MA, Al-thobhani AK et al. Clinical and experimental evaluation of the effect of khat-induced myocardial infarction. Saudi Medical Journal. 2002;23:1195-8.

[34]. Mujlli HM, Bo X, Yhang L. The effect of Miraa (Catha edulis) on acute cerebral infarction. Neuroscience. 10:219-22.

[35]. Balint EE, Falkay G, Balint GA. Miraa- a controversial plant. Wien Klin Wochenschr. 2009;121:604-14.

[36]. Mwenda JM, Arimi MM, Kyama MC et al. Effects of miraa- consumption on reproductie function. East Africa Medical Journal. $2003 ; 80: 318-23$.

[37]. International Agency for Research on cancer. Tobacco smoke and involuntary smoking. IARC monographs on the evaluation of the carcinogenic risk of chemicals to humans. Lyon: IARC. 2004;

[38]. World Health Organization. Cancer in Africa-statistics. International Agency for Research on cancer. 2008;

[39]. American Cancer Society. What Are Oral Cavity and Oropharyngeal Cancers? 2012.

[40]. 40.4 Merck M. Mouth and Dental Disorders: http://www.merckmanuals.com/home/mouth_and_dental_disorders/mouth_growths/cancerous_mouth_growths.html?qt=\&sc=\&alt= 2012.

[41]. American Cancer Society. Cancer Facts \& Figures 2012. American Cancer Society. 2012 p. 17.

[42]. Soufi HE, Kameswaran M, Malatani T. Khat and oral cancer. The Journal of laryngology and otology 1991 Aug;105(8):643-5.

[43]. Hill C.M, Gibson A. The oral and dental effects of khat chewing. Oral surgery oral medicine oral pathology oral radiology and endodontic $63 ; 1987 ; 63: 433-6$.

[44]. Goldenberg D, Lee J, Koch WM et al. Habitual risk factors for head and neck cancer. Otolaryngol Head Neck Surgery. 2004; 131(6):986-93.

[45]. Kassie F, Darroudi F, Kundi M et al. Miraa (Catha edulis) consumption causes genotoxic effects in humans. International Journal of cancer research. 2001;92(3):329-32. 
[46]. Nasr AH, Miraaari M. Head and neck squamous cell carcinoma in Hajjah, Yemen. Saudi Med ical Journal. 2000;21(6):565-8.

[47]. Scuibba J. Improving detection of precancerous and cancerous oral lesions. JADA. 1999;130:1445.

[48]. Wesley R, Sankaranarayanan R, Matthew B et al. Evaluation of visual inspection as a screening test for cervical cancer. British Journal of Cancer. 1997;75:436-40.

[49]. Sciubba JJ, Patterson W, Well J et al. Oral brush biopsy with computer-assisted analysis. www.emedicine.com. 2004.

[50]. Gorsky M, Epstein JB, Levi H et al. Oral white lesions associated with chewing khat. PTID Society Tobacco induced diseases Vol. 2 No. 3:145-150(2004)

\section{Appendinces}

\section{Appendix I: INFORMED CONSENT FORMS}

Topic: Oral mucosal cytological changes among miraa chewers in Meru Kenya

Consent explanation: My name is Ogada Nelly Akinyi (Tel: 0721442017) a Master student at the Department of Human Pathology, University of Nairobi. PO Box 20732 Nairobi, Kenya; Phone: +254-2-7263000 Ext 43769. I am conducting a study seeking to find out what is the effect of routine miraa chewing on your mouth tissues. The information in this form will help you make an informed decision whether or not to participate in this study. Please read through carefully and feel free to ask any question about the study. I will read it out to those who are not able to read.

Description: Previous studies in other regions have shown that those people who routinely chew miraa are likely to develop changes in their mouths which could lead to cancer.

Purpose: This study is interested in finding out what are the changes likely to cause cancer of the mouth among those who routinely chew miraa in Meru.

Benefits: You will benefit from free screening of your mouth for cancerous tissues. In case of any abnormal findings you will be counseled, informed in confidentiality and referred to where you will receive care and early management.

Risks: One potential risk of being in the study is the loss of privacy. However, we will do our best to make sure that the personal information gathered during this study is kept private. Also, you might feel a little discomfort at the time we will be taking your mouth samples.

Procedure: If you accept to participate in this study, we will ask you to attend the Meru level $\mathrm{V}$ dental unit where you will meet study consultant. You will undergo face to face interviews using language you are comfortable with to answer a few questions concerning your demographic parameters as well as collect mouth sample from you using special brush.

Voluntarism: Participation in this research study will be voluntarily without any coercion

Follow up: Participants found with abnormal mouth finding will be contacted for review and referral to a management facility.

Subject's rights: If you have read this form and have decided to participate in this project, please understand your participation is voluntary and you have the right to withdraw your consent or discontinue participating at any time without penalty. You have the right to refuse to answer particular questions. Your individual privacy will be maintained in all published and written data resulting from the study.

If you have questions about your rights as a study participant, or are dissatisfied at any time with any aspect of this study, you may contact - anonymously, if you wish - KNH/UoN ERC (Chairperson of the Scientific Steering Committee, PO Box 20732 Nairobi, Kenya; Phone: 02-7263000 Ext 44102.

I have read this form or had it read to me in a language that I understand. I have discussed the information with study staff. My questions have been answered. My decision whether or not to take part in the study is voluntary. If I decide to join the study I may withdraw at any time. By signing this form I do not give up any rights that I have as a research participant.

Participant Name

Participant Signature/ Thumbprint Date

$\overline{\text { Study Staff Conducting }}$ Study Staff Signature $\quad$ Date

\section{Fomu ya Idhini (Kiswahili)}

\section{Maelezo}

Jina langu ni Ogada Nelly Akinyi kutoka Idara ya Human Pathology katika Chuo kikuu cha Nairobi. Lengo la ujumbe huu ni kutoa maelezo kwako kuhusu utafiti nitakao fanya, na kupata idhini kutoka kwako kushiriki kwa hiari ili nitafiti na kujua kama umeadhirika au la. Waweza kuuliza maswali kuhusu utafiti huu, uzuri wake na madhara ambayo yaweza kukupata. Maswali yote utajibiwa wazi wazi, na ni hiari yako kushiriki au kutoshiriki bila kushurutishwa. Fomu hii ina ujumbe utakao hitaji kukuwezesha kufanya uamuzi mwafaka. Ikiwa huwezi kusoma, nitakusomea kwa sauti ili uweze kuelewa 
2. Utafiti wa kisaitologia kuchunguza mabadiliko ya patikanayo kwa vinywa vya watu wanao tafuna miraa Meru Kenya.

\section{Madhumuni na faida ya utafiti}

Lengo la utafiti huu ni kubaini twakimu za saratani na dalili zake katika watu wanao tafuna miraa Nairobi nchini Kenya

Baada ya uchunguzi, utaelezwa faraghani matokeo yako na uelekezwe zaidi kuhusu matibabu au kinga.

Ugunduzi wa mapema wa dalili za saratani ni bora zaidi ili kujua matibabu yafaayo mapema.Kipimo hiki hakifanywi kwa kawaida humu nchini, na watu wanao tafuna miraa hawajui kama wana dalili za saratani au la. Uchunguzi huu utawasaidia watu hawa kujua hali zao na kupata matibabu mwafaka.

\section{Madhara}

Baadhi ya maswali utakayoulizwa yatakuwa ni ya siri sana, au ya kukuudhi, lakini tunakuhakikishia kuwa siri zako hazitatolewa nje. Una haki ya kujibu au kutojibu maswali ikiwa hayakuridhishi, kutamatisha mahojiano au kujiondoa katika utafiti huu upendapo.

Waweza kuwa na wasiwasi kuhusu matokeo ya uchunguzi, lakini utapewa hakikisho na ushauri ufaao. Unahakikishiwa kuwa stakabadhi zako zitahifadhiwa kwa njia inayofaa na hakuna mtu yeyote ataruhusiwa kuzisoma.

Ikiwa matokeo hayatakuwa mazuri, utapewa ushauri kuhusu matibabu ipasavyo.

\section{Utaratibu wa kushiriki}

Ukiamua kushiriki, utapewa maswali kwenye dodoso utakayojibu kwa njia mwafaka. Utaratibu utakaofuatwa ndio huu.

Baada ya kusukutua na kuosha mdomo kutumia maji, chombo maalum kita ingizwa mdomoni na kuchukua chembechembe za ngozi kutoka mahala pa kutafunia miraa. Kipimo hiki kitachungunzwa kwenye mahabara il kubaini dalili za saratani.Utaelezewa matokeo yako kwa njia ya faragha. Matokeo haya yatatumiwa kukupa matibabu ikiwa matokeo hayatakuwa mazuri.

Una maswali yoyote? Ndio.

La.

Umeamua kushiriki? Ndio......

..La. . .

\section{Idhini ya mshiriki}

Nimeshauriwa kamili kuhusu utafiti huu na nimeamua bila kushurutishwa na yeyote kushiriki. Nikiwa na maswali yoyote kuhusu utafiti huu nitamjulisha mwenyekiti, kamati ya maadili ya utafiti ya Hospitali kuu ya Kenyatta/ Chuo kikuu cha Nairobi kupitia simu:

020-726300-44102.

Ikiwa nitahitajika baadaye, nitajulishwa kupitia nambari za simu nilizopeana.

Jina la mshiriki. .Namba ya simu.

Sahihi. .... Tarehe.

Jina la shahidi.....

Sahihi................................ Tarehe.

Appendix II: PHOTOGRAPHS AND PHOTOMICROGRAPHS

1. Photographs of miraa plant

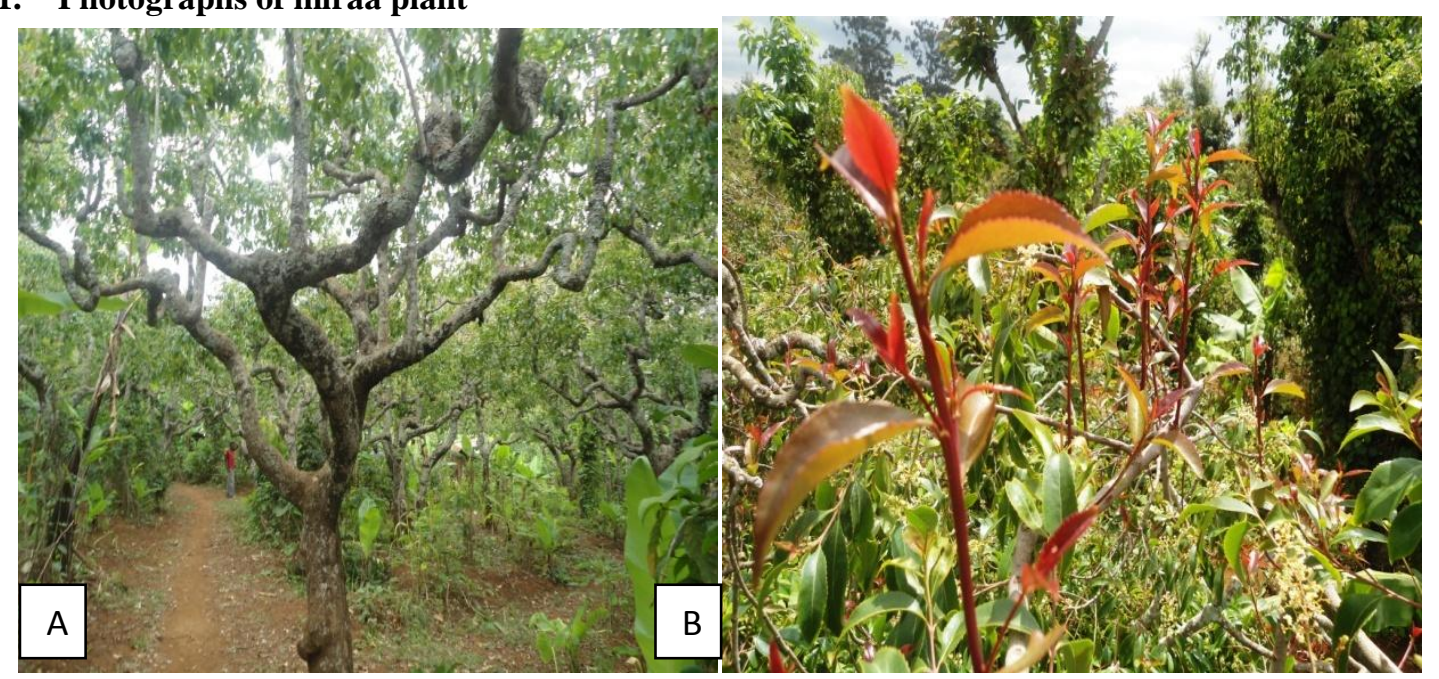



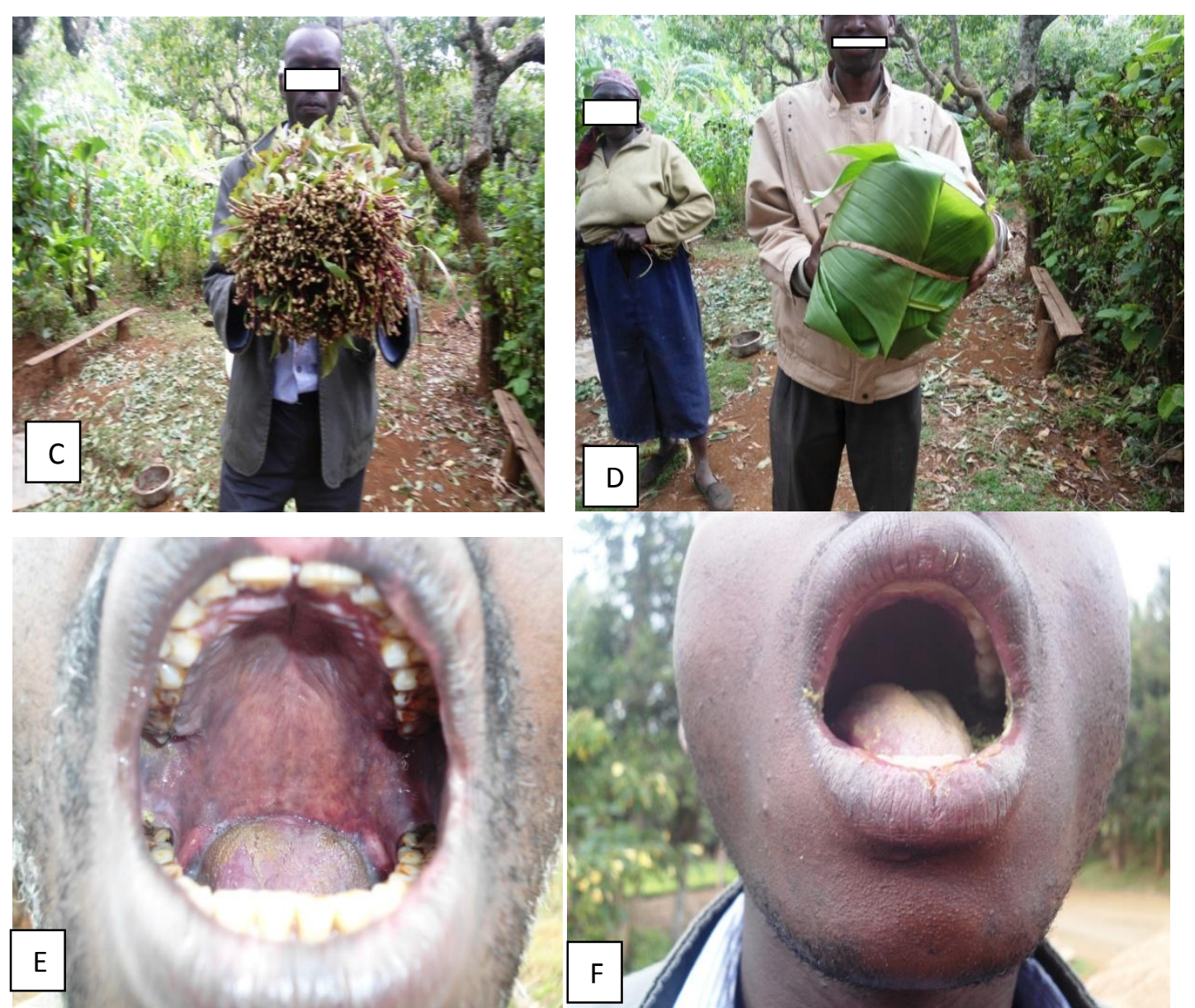

A-Miraa plants, B-Shoots ready for harvesting, C-Bundle of shoots, D-shoots wrapped in banana leaves for the market, E-brown discolouration of teeth, F-Ulcerated lips. 
2. Photomicrographs showing cytology findings

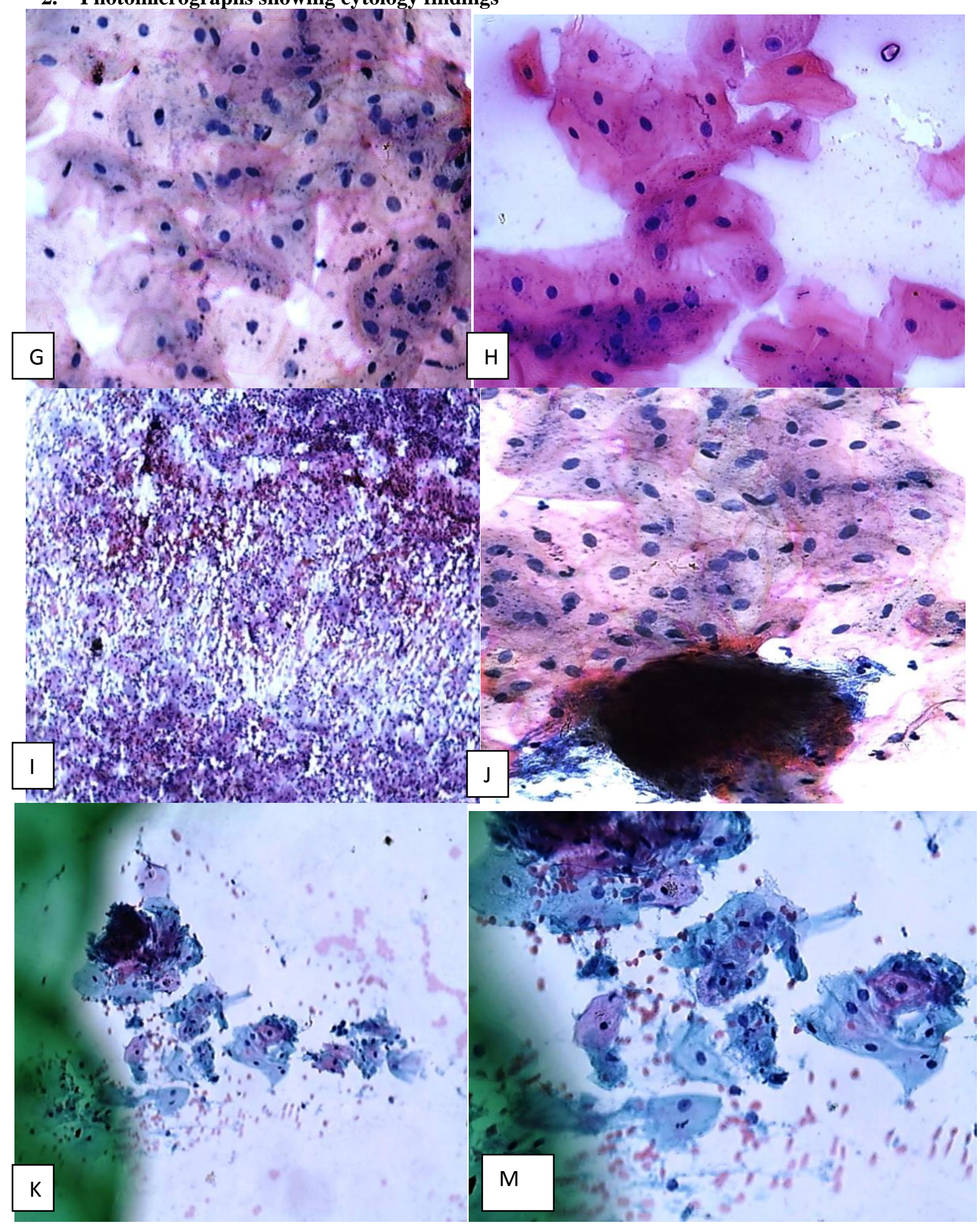

G-Normal squamous cells (x40) Pap stains, H-Normal squamous cells (x40) H\&E stain, I-Inflammatory smear(x10) Pap stain, J-Normal squamous cells with contaminant (x40) Pap stain, K-Atypical cells (x20) Pap stain and M- Atypical cells (x40) Pap satin 
3. Cytobrush
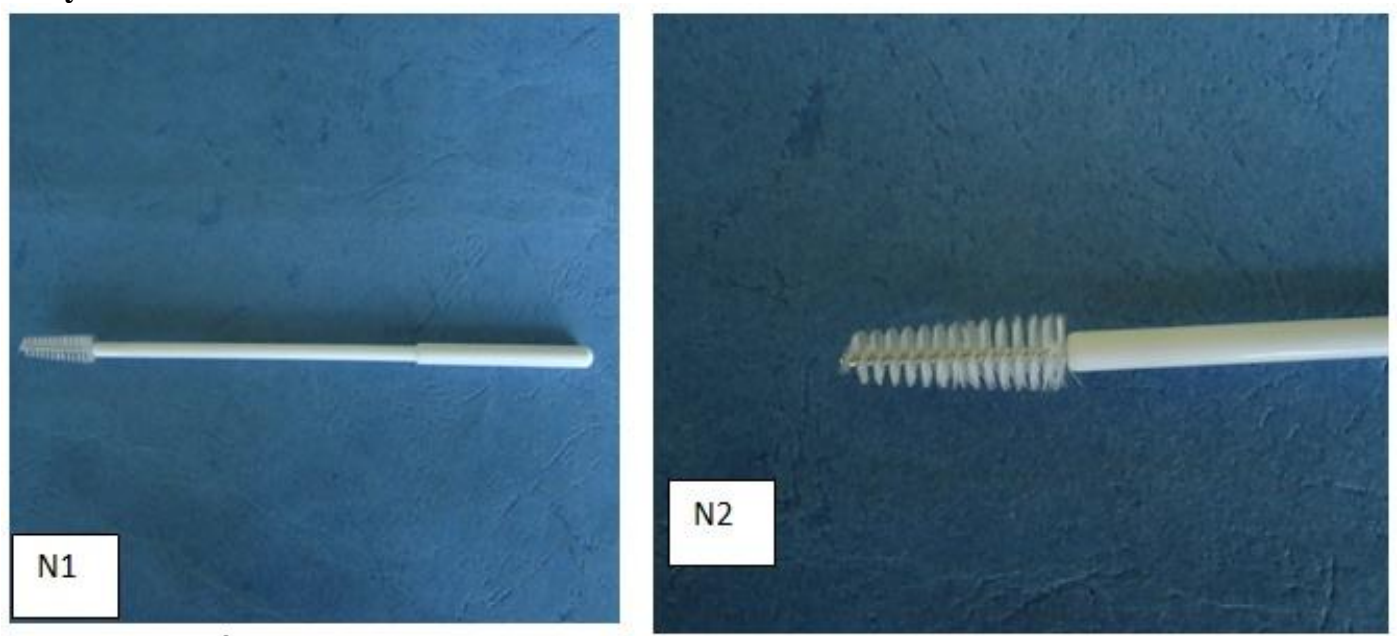

N1 and N2 cytobrush

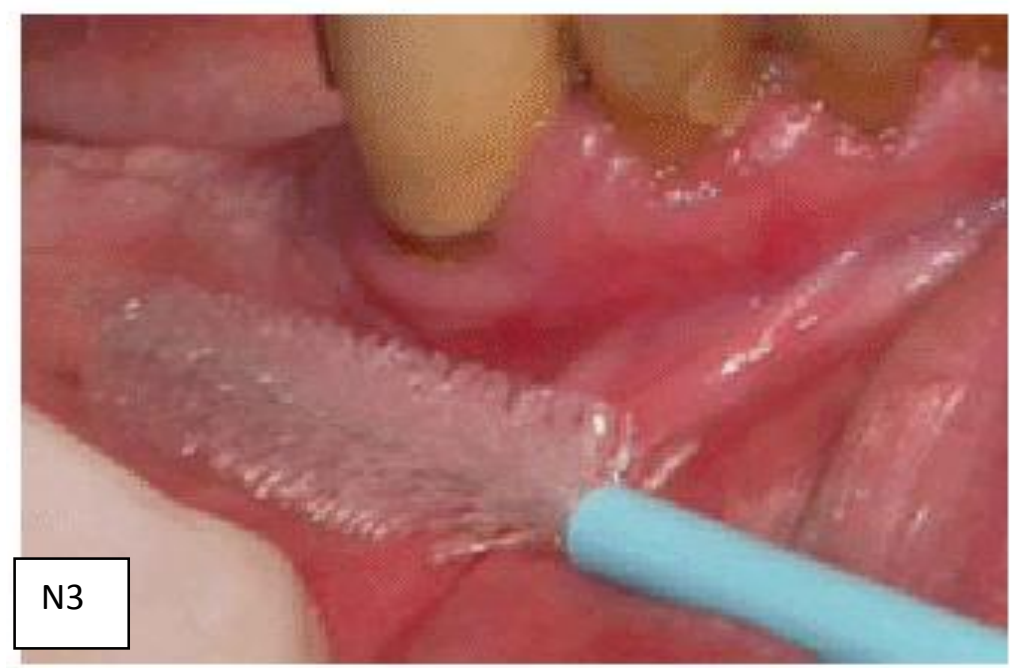

N3: Collection of smear with the cytobrush

\section{Appendix III: QUESTIONNAIRE}

The oral mucosal cytological changes among miraa chewers in Meru Kenya.

The participants will fill the questionnaire before oral smears are collected.

Section 1: Social demographic data

1. Study number Date $(\mathrm{d} / \mathrm{m} / \mathrm{y})$

2. Sex: Male $\square$ Female $\square \quad$ Age

3. Occupation: Miraa farmer $\square$

Miraa seller

Others (specify)

4. Are you a residence of Meru Town? Yes

If No, specify area of residence

5. Marital status: Single

\section{Married}

Divorced

Windowed

6. What is your level of education?

None

Primary $\square$

Secondary

Tertiary $\square$

7. How long have you chewed miraa? (Years) 
$\leq 5$

$5-10$

$\geq 10$

8 . How many bundles of miraa do you chew in a day?

$\leq 1$

$1-3$

$\geq 3$

9. How often do you chew miraa?

Daily

Once in a week

Occasionally

10. How long does the bolus stay in your mouth? (Hours)

$1-6$

6- 12

$\geq 12$

11. Do you smoke? $\quad$ Yes $\quad \square \quad$ No

If yes, specify: Tobacco (sniffed)

Smokeless Tobacco

Cigarettes

Bhang

12. Do you drink alcohol? Yes

If yes, specify: a) Bottled

b) Quantity per day:

$\leq 5$ bottles

$6-10$ bottles

$\geq 10$ bottles

c) Duration of use (yr):

$\leq 5$

$5-10$

$\geq 10$

13. Do you use/chew other drugs? Yes $\square \quad$ No

If yes specify; Name and Mode of intake

14. Do you have a lesion in the oral cavity? Yes $\quad \square \quad$ No

If yes, are you under any medication for the same? Yes

No $\quad \square \quad$ Specify

FOR LABORATORY USE ONLY

RESULTS: Oral cavity Cytology

Specimen Adequacy

Satisfactory

Unsatisfactory

Epithelial cell features

Negative

Inflammatory

LSIL

ASC $-\mathrm{H}$

HSIL

SCC $\quad \square \quad$ Others, Specify... 


\section{Appendix IV: LABORATORY METHODS \\ Papanicolaou Staining Procedure \\ 2.1 Principle of the stain}

Hematoxylin stains the nuclei blue by dye lake formation. The eosin azure solution being acidic stains the cytoplasm which is basic so that the eosin has affinity for the mature cells while light green has affinity for the young cells. Orange $\mathrm{G}$ also being an acidic dye has an affinity for the cytoplasm and stains keratin.

\subsection{Staining technique}

1. Slides with smears will be fixed in $95 \%$ ethanol for 15 minutes.

2. Hydrated in descending grades of alcohol, 80\%, 70\%, 50\%, 10 dips in each.

3. Rinsed in tap water, 10 dips.

4. Stained with Harris Hematoxylin stain for 4 minutes.

5. Rinsed in tap water until excess stain is drained off.

6. Differentiated in three changes of $0.05 \%$ acid alcohol, 10 dips in each.

7. Rinsed in running tap water.

8. Blued in Scott's tap water for 1 minute, and rinsed in tap water, 10 dips.

9. Dehydrated in ascending grades of alcohol, 70\%, 90\%, 10 dips in each.

10. Stained with Orange G-6 for 2 minutes.

11. Dehydrated in three changes of $95 \%$ alcohol, 10 dips in each.

12. Stained in Eosin Azure EA-36 for 3 minutes.

13. Dehydrated in three changes of $95 \%$ alcohol, 10 dips in each.

14. Cleared in three changes of xylene, 10 dips in each.

15. Mounted with DPX (Diestrene Plasticizer Xylene), and observed under microscope.

\subsection{Reagent preparation}

\subsubsection{Harris alum hematoxylin}

To prepare $2000 \mathrm{mls}$

1. Hematoxylin

2. Absolute alcohol

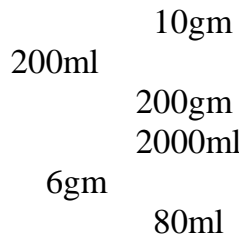

\section{Method of preparation}

3. Ammonium alum

4. Distilled water

5. Mercuric oxide

6. Glacial acetic acid

$80 \mathrm{ml}$

1. Dissolve Hematoxylin in absolute alcohol (Solution 1).

2. Dissolve Ammonium alum in water (Solution 2).

3. Mix solution 1and solution 2 and heat to boil.

4. Add mercuric oxide and cool rapidly.

5. Add glacial acetic acid.

6. Solution is ready for use as soon as it cools.

7. Filter before use

\subsubsection{E.A.36}

To prepare 4 litres
1. Light green
2. Bismark brown
3. Eosin yellow
4. Phosphotungstic acid

$\begin{array}{ll} & 2 \mathrm{gm} \\ & \\ & 10 \mathrm{gm} \\ & 8 \mathrm{gm} \\ & 1200 \mathrm{ml}\end{array}$
5. Distilled water
6. Absolute ethanol
$2800 \mathrm{ml}$
7. Glacial acetic acid
$40 \mathrm{ml}$

\section{Method of preparation}

1. Dissolve in order of light green then bismark brown then eosin yellow into water.

2. Add phosphotungstic acid slowly in stages while agitating

3. Add alcohol slowly while agitating

4. Add glacial acetic acid then agitate

* ph of E.A.36 should be 4.5-5 to achieve maximum results. 


\subsubsection{O.G 6}

To prepare 4 litres

1. Orange green(O.G)

$9.4 \mathrm{gm}$

2. Phosphotungstic acid

$0.6 \mathrm{gm}$

3. Distilled water

$1200 \mathrm{ml}$

4. Absolute ethanol $2800 \mathrm{ml}$

Preparation Method

1. Dissolve O.G in water then phosphotungstic acid

2. Add absolute ethanol

\subsection{5\% acid alcohol}

To prepare I litre of $0.05 \%$ acid alcohol

1. Distilled water

$999.5 \mathrm{ml}$

2. Conc.HCL

$0.5 \mathrm{ml}$

\subsubsection{Scotts tap water}

To prepare $1000 \mathrm{ml}$

1. Sodium bicarbonate

$3.5 \mathrm{gm}$

2. Magnesium sulphate

$20 \mathrm{gm}$

3. Distilled water

4. Thymol

1 tablet

\subsection{Quality check}

1. Stains will be stored in dark colored, stoppered bottles.

2. Fresh amounts of Hematoxylin will be added to replace stain loss due to evaporation.

3. O.G and E.A were replaced as soon as the cells appear without crisp staining colors.

4. Water rinses will be done under running tap water.

5. Alcohol will be replaced on a rotating basis

6. Xylene will be changed as soon as it becomes tinted with any of the cytoplasmic stains or becomes slightly milky due to presence of water.

7. An agitation of the slides by dipping will be done to remove excess dye.

8. Dipping will be done gently to avoid cell loss and the slide carrier was not hit the bottom of the staining dish.

\section{Appendix V: BETHESDA SYSTEM FOR REPORTING CERVICAL CYTOLOGY}

1. SPECIMEN ADEQUACY

- Squamous cellularity

- Unsatisfactory

- Satisfactory

- Transformation zone component

- Obscuring factors

2. NON-NEOPLASTIC FINDINGS

a) Organisms

- Trichomonas vaginalis

- Fungal organisms morphologically consistent with Candida spp

- Cellular changes consistent with Herpes simplex virus

b) Other non-neoplastic findings (Optional to report; list not inclusive)

- Reactive cellular changes associated with:

- Inflammation (includes typical repair)

- Radiation

c) Non-neoplastic findings, not specifically listed in 2001 Bethesda terminology

- Keratotic cellular changes

- Lymphomas

- Other

2. ATYPICAL SQUAMOUS CELLS

a) Of undetermined significance (ASC-US)

b) Cannot exclude HSIL (ASC-H) 


\section{EPITHELIAL ABNORMALITIES: SQUAMOUS}

a. Low grade squamous intraepithelial lesion (LSIL)

Encompassing: HPV/mild dysplasia/CIN 1

b. High grade squamous intraepithelial lesion (HSIL)

Encompassing: moderate and severe dysplasia, CIS; CIN 2 and CIN 3

With features suspicious for invasion (if invasion is suspected)

c. Squamous cell carcinoma

Squamous epithelial abnormalities, not specifically listed in 2001 Bethesda terminology

- Keratinizing lesions

- Squamous intraepithelial lesions (SIL) - borderline cases

-SIL with gland involvement

3. EPITHELIAL ABNORMALITIES: GLANDULAR

Atypical Glandular cells, NOS or specify in comments

- AtypicalGlandular cells, favor neoplastic

-Adenocarcinoma

-Not otherwise specified (NOS)

4. OTHER MALIGNANT NEOPLASMS

-Carcinomas

-Sarcomas

-Other tumors

\section{ORAL CYTOLOGY}

-Unsatisfactory

- NILM: Negative for intraepithelial lesion or malignancy

-Epithelial cell abnormalities 